\title{
ANALISIS RASIO LIKUIDITAS, RASIO PROFITABILITAS, DAN ECONOMIC VALUE ADDED (EVA) PADA KINERJA KEUANGAN PT. SIANTAR TOP Tbk (Periode 2011-2014)
}

\author{
Moh. Zaki Kurniawan \\ Dosen Fakultas Ekonomi Universitas Islam Balitar Blitar \\ e-mail: zaki.kurniawan3@gmail.com
}

\begin{abstract}
ABSTRAK
Tujuan penelitian ini adalah untuk mengetahui kinerja keuangan PT. Siantar Top Tbk yang diukur menggunakan rasio likuiditas, rasio profitabilitas, dan EVA berdasarkan laporan keuangan periode 2011-2014. Alat analisis yang digunakan untuk mengukur rasio likuiditas adalah rasio rasio lancar dan Quick Ratio, untuk rasio profitabilitas adalah profit margin, Return On Assets (ROA), Return On Equity (ROE), dan metode Economic Value Added (EVA). Berdasarkan hasil analisis dan pembahasan, kinerja keuangan PT. Siantar Top Tbk: 1) rasio likuiditas PT. Siantar Top Tbk masuk dalam kategori tidak baik untuk rasio lancar dan quick ratio. 2) rasio profitabilitas PT. Siantar Top Tbk masuk dalam kategori tidak sehat untuk profit margin, baik sekali untuk ROA dan ROE. 3) EVA PT. Siantar Top Tbk masuk dalam kategori negatif.
\end{abstract}

Kata kunci: rasio likuiditas, rasio profitabilitas, EVA, kinerja keuangan.

\section{PENDAHULUAN}

Kinerja keuangan perusahaan merupakan hasil dari banyak keputusan individual yang dibuat secara terus menerus oleh manajemen. Metode penelitian keuangan perusahaan harus didasarkan pada data keuangan yang dipublikasikan yang dibuat sesuai dengan prinsip akuntansi keuangan yang berlaku umum. Informasi akuntansi keuangan merupakan dasar yang objektif dan bukan subjektif sebagai dasar penilaian kinerja manajemen. Pelaporan keuangan sebagai salah satu sumber informasi bagi manajemen merupakan sebuah ikhtisar yang dapat membantu pihak manajemen dalam melakukan pengambilan keputusan. Analisa laporan kinerja keuangan merupakan salah satu alat yang dapat dipergunakan untuk mendapatkan informasi manajemen terutama berkaitan dengan kondisi keuangan perusahaan.

Untuk menilai kondisi keuangan dan prestasi perusahaan, analisis keuangan memerlukan beberapa tolak ukur. Tolak ukur yang sering dipakai adalah rasio atau indeks, yang membandingkan satu laporan keuangan dengan lainnya yang mempunyai hubungan yang relevan dan signifikan. Sarana yang penting digunakan untuk mengukur tingkat kinerja keuangan adalah rasio keuangan. Ada berbagai rasio yang dapat menunjukan kinerja keuangan perusahaan. Salah satu rasio keuangan yang digunakan dalam penelitian ini adalah rasio Likuiditas, Rasio profitabilitas dan EVA. Rasio yang digunakan dari rasio Likuiditas adalah rasio lancar. Rasio yang digunakan dari rasio profitabilitas adalah Profit Margin. 
Alasan memilih rasio likuiditas adalah karena rasio likuiditas akan mampu mengukur kemampuan likuiditas perusahaan jangka pendek dengan melihat besarnya aktiva lancar terhadap utang lancarnya. Alasan memilih rasio profitabilitas adalah karena rasio profitabilitas akan mampu mengukur sejauh mana kemampuan perusahaan dalam menghasilkan laba. Selain sebagai tujuan utama perusahaan, laba merupakan indikator bagi perusahaan. Laba adalah faktor utama dalam mengukur tingkat efektifitas dan efisiensi suatu perusahaan dengan seluruh dana dan sumberdaya yang ada di perusahaan. Alasan memilih EVA adalah karena EVA akan mampu mengukur sejauh mana perusahaan memperoleh nilai tambah dengan menggabungkan perolehan nilai biaya

\section{Laporan Keuangan Perusahaan}

Laporan keuangan adalah laporan pertanggungjawaban manajer atau pimpinan perusahaan atas pengelolaan perusahaan yang dipercayakan kepadanya kepada pihak-pihak yang berkepentingan (stakeholder) terhadap perusahaan yaitu pemilik perusahaan (pemegang saham), pemerintah (instansi pajak), kreditur (bank atau lembaga keuangan), maupun pihak yang berkepentingan lainnya (Rahardjo (2007:53). Laporan keuangan merupakan hasil akhir dari proses akuntansi, yang meliputi (1) neraca, (2) perhitungan rugi-laba dan yang ditahan, (3) laporan perubahan posisi keuangan serta catatan atas laporan keuangan (Harnanto, 1991:9).

\section{Tujuan Laporan Keuangan}

Tujuan laporan keuangan secara umum adalah menyediakan informasi tentang posisi keuangan, kinerja keuangan, dan laporan arus kas suatu entitas yang bermanfaat bagi sejumlah besar pengguna dalam pengambilan keputusan ekonomi. Utuk memenuhi tujuannya, laporan keuangan juga menunjukan apa yang telah dilakukan manjemen (stewardship) atau pertanggungjawaban manajemen atas sumber daya yang dipercayakan.

Menurut Rudianto (2012:20), tujuan penyajian laporan keuangan oleh sebuah entitas sebagai berikut :

1. Untuk memberikan informasi keuangan yang dapat dipercaya mengenai sumber-sumber ekonomi dan kewajiban serta modal perusahaan.

2. Untuk memberikan informasi yang dapat dipercaya mengenai perubahan sumber-sumber ekonomi perusahaan yang timbul dalam aktivitas usaha demi memperoleh laba.

3. Untuk memberikan informasi keuangan yang membantu para pemakai laporan keuangan untuk mengestimasi potensi perusahaan dalam menghasilkan laba di masa depan.

4. Untuk memberikan informasi keuangan yang membantu para pemakai laporan keuangan ketika mengestimasi potensi perusahaan dalam menghasilkan laba.

5. Untuk memberikan informasi penting lainnya mengenai perubahan sumbersumber ekonomi dan kewajiban seperti informasi tentang aktivitas pembiayaan dan investasi. 
6. Untuk mengungkapkan sejauh mungkin informasi lain yang berhubungan dengan laporan keuangan yang relevan untuk kebutuhan pemakai laporan, seperti informasi mengenai kebijakan akuntansi yang dianut perusahaan.

Menurut Harnanto (1991:11), laporan keuangan yang disusun dan disajikan kepada semua pihak yang berkepentingan dengan eksistensi suatu perusahaan, pada hakekatnya merupakan alat komunikasi. Artinya laporan keuangan itu adalah suatu alat yang digunakan untuk mengkomunikasikan informasi keuangan dari suatu perusahaan dan kegiatan-kegiatannya kepada mereka yang berkepentingan dengan perusahaan tersebut. Secar garis besar pihak-pihak yang berkepentingan dengan eksistensi suatu perusahaan itu dapat dibedakan menjadi dua golongan, yaitu: pihak ekstern dan pihak intern. Dalam kaitannya dengan pihak-pihak yang berkepentingan itu, laporan keuangan seperti dikemukakan tersebut di atas terutama ditujukan dan lebih banyak berorientasi kepada kepentingan pihak ekstern yang terdiri dari banyak pihak. Namun tidak berarti bahwa laporan keuangan, tidak berguna bagi pihak intern (khususnya manajemen).

Sementara itu pihak ekstern terdiri dari banyak pihak, antara lain: pemilik dan calon pemilik, kreditur dan calon kreditur, instansi pemerintah, langganan, leveransir, dll. Kepada mereka inilah laporan keuangan yang disusun oleh perusahaan itu ditujukan. Melalui laporan keuangan yang dipublikasikan (oleh suatu perusahaan) masing-masing pihak yang tergabung dalam kelompok pihak ekstern ini ingin dan dapat memperoleh informasi keuangan yang bersangkut paut dengan perusahaan tersebut, seperti:

1. Pemilik dan calon pemilik (pemegang saham)

Para pemilik perusahaan ingin mengetahui sukses yang telah dicapai oleh perusahaan, guna meramalkan kemungkinan yang akan terjadi di masa yang akan datang. Informasi ini penting untuk di pakai sebagai dasar membuat keputusan apakah ia akan tetap mempertahankan pemilik saham-sahamnya pada perusahaan tersebut atau lebih baik menjualnya saja bagi para pemilik atau pemegang saham. Di lain pihak para calon pemilik, menggunakan informasi tersebut untuk membuat keputusan apakah membeli saham-saham perusahaan atau menanamkan dananya pada alternatif investasi (yang lain).

2. Kreditur dan Calon Kreditur

Para kreditur ingin mengetahui apakah pinjaman yang diberikan kepada perusahaan dipergunakan sebagai mana mestinya, sehingga memungkinkan perusahaan untuk dapat membayar kembali hutang beserta bunganya. Informasi demikian itu penting untuk dipakai sebagai dasar membuat keputusan, apakah negosiasi perlu dibuat, apakah perpanjangan waktu pembayaran dan perluasan kredit dapat disetujui, apakah pensitaan jaminan perlu dilakukan dan lain-lain.

3. Instansi Pemerintah

Pihak pemerintah ingin mengetahui banyak aspek yang menyangkut suatu perusahaan, antara lain: jumlah pajak yang dibayar, jumlah tenaga kerja yang diserap oleh perusahaan.

4. Langganan dan Leveransir (supplier) 
Untuk mengetahui apakah supplier tersebut tetap bekerja sama dengan perusahaan tersebut atau tidak.

\section{Analisis Rasio Keuangan Perusahaan}

Rasio Likuidias mengukur kemampuan likuiditas jangka pendek perusahaan dengan melihat besarnya aktiva lancer relative terhadap utang lancarnya. Utang dalam hal ini merupakan kewajiban perusahaan. Salah satunya rasio lancar yaitu kemampuan perusahaan memenuhi utang jangka pendeknya (jatuh tempo kurang dari satu tahun) dengan menggunakan aktiva lancar. Rasio yang rendah menunjukkan likuiditas jangka pendek yang rendah. Rasio lancar yang tinggi menunjukkan kelebihan aktiva lancar (likuiditas yang tinggi dan risiko rendah), tetapi mempunyai pengaruh yang tidak baik terhadap profitabilitas perusahaan. (Hanafi (2015:37)). Rasio lancar dapat di hitung dengan rumus sebagai berikut:

$$
\text { Rasio lancar }=\frac{\text { Aktiva Lancar }}{\text { Utang Lancar }}
$$

Rasio Profitabilitas mengukur kemampuan perusahaan menghasilkan keuntungan (profitabilitas) pada tingkat penjualan, asset, dan modal saham tertentu. Ada tiga rasio yang sering digunakan, salah satunya yaitu profit margin menghitung sejauh mana kemampuan perusahaan menghasilkan laba bersih pada tingkat penjualan tertentu. Rasio ini bisa juga diinterpretasikan sebagai kemampuan perusahaan menekan biaya-biaya di perusahaan pada periode tertentu. Profit Margin yang tinggi menunjukkan kemampuan perusahaan menghasilkan laba yang tinggi pada tingkat penjualan tertentu (Hanafi (2015:42)). Profit Margin bisa dihitung sebagai berikut:

$$
\text { Profit Margin }=\frac{\text { Laba Bersih }}{\text { Penjualan }}
$$

EVA merupakan ukuran kinerja yang menggabungkan perolehan nilai yang biaya untuk memperoleh nilai tambah tersebut. Pendekatan EVA yang dikembangkan oleh lembaga konsultan manajemen asal Amerika Serikat, Sten Steward Management Service pada pertengahan 1990-an. Metode penilaian kinerja dengan menggunakan data akutansi seperti yang di bahas sebelumnya belum sepenuhnya sesuai dengan tujuan memaksimalkan kemakmuran pemegang saham sehingga perlu perhitungan untuk mengidentifikasikan kinerja perusahaan. Dari sisi pertumbuhan nilai ekonomis perusahaan yang diprediksi dengan analisis EVA (Hanafi (2015:53)).

$$
\text { Rumus: EVA = NOPAT }- \text { Biaya Modal }
$$

\section{Kinerja Keuangan Perusahaan}

Kinerja keuangan merupakan tolok ukur bagi manajemen perusahaan dalam mengambil keputusan. Besar kecilnya kinerja yang dicapai tergantung pada manajemen perusahaan baik dari masing-masing individu maupun kelompok dalam perusahaan tersebut. Kinerja adalah hasil-hasil fungsi pekerjaan atau kegiatan seseorang atau kelompok dalam suatu organisasi yang dipengaruhi oleh beberapa faktor untuk mencapai tujuan organisasi dalam periode tertentu (Tika dalam Rudianto (2012:121)). 


\section{Kerangka Pikir Penelitian}

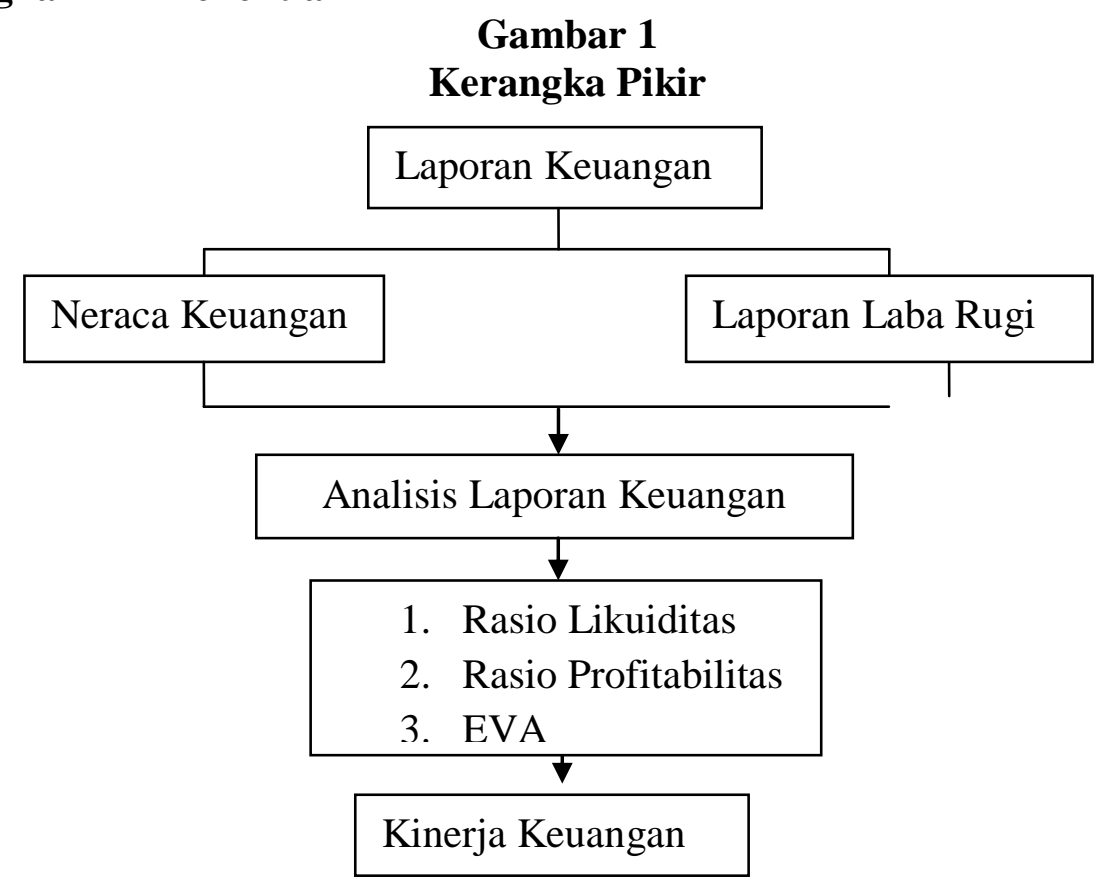

\section{METODE PENELITIAN}

\section{Jenis Data}

Jenis data yang digunakan dalam penelitian ini adalah kuantitatif. Metode kuantitatif adalah metode penelitian yang berlandaskan pada filsafat positivism yang digunakan untuk meneliti pada populasi atau sampel, pengumpulan data menggunakan instrument penelitian analisis data yang bersifat kuantitatif/statistik dengan tujuan untuk menguji hipotesis yang telah ditetapkan. Alasan menggunakan motode kuantitatif karena memandang realita/fenomena yang dapat diklasifikasikan, konkrit dan terukur (Sugiono (2015:8).

\section{Variabel dan Pengukuran}

Tabel 1

Variabel dan Indikator Pengukuran

\begin{tabular}{|c|c|c|}
\hline $\mathrm{NO}$ & ANALISIS RASIO & RUMUS \\
\hline \multirow{3}{*}{1} & \multirow{3}{*}{ Rasio Lancar } & Aktiva Lancar \\
\hline & & $\overline{\text { Utang Lancar }}$ \\
\hline & & Sumber : Mamduh M. Hanafi (2004:37) \\
\hline \multirow{3}{*}{2} & \multirow{3}{*}{ Profit Margin } & Laba Bersih \\
\hline & & Penjualan \\
\hline & & Sumber : Mamduh M. Hanafi (2004:42) \\
\hline 3 & EVA & $\begin{array}{c}\text { NOPAT - Biaya Modal } \\
\text { Sumber: Mamduh M. Hanafi }(2004: 53)\end{array}$ \\
\hline
\end{tabular}

Teknik Analisis Data

Gambar 2

Teknik Analisis Data 


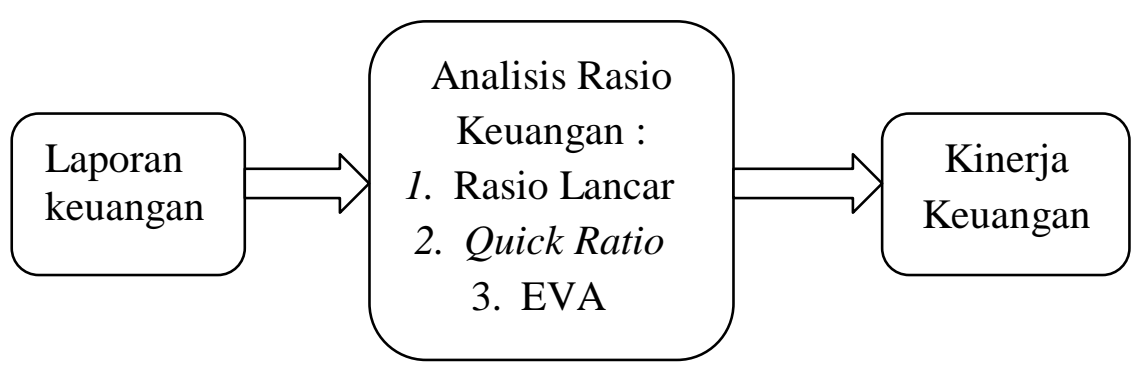

\section{HASIL DAN PEMBAHASAN \\ Rasio Likuiditas}

Rasio Lancar

Tabel 2

Hasil Perhitungan Rasio Lancar Periode 2011 - 2014

(dalam milyar rupiah)

\begin{tabular}{|l|l|l|l|l|}
\hline Keterangan & $\mathbf{2 0 1 1}$ & $\mathbf{2 0 1 2}$ & $\mathbf{2 0 1 3}$ & $\mathbf{2 0 1 4}$ \\
\hline $\begin{array}{l}\text { Rasio Lancar } \\
\text { (dalam bentuk desimal) }\end{array}$ & 0,952 & 0,997 & 1,142 & 1,484 \\
\hline $\begin{array}{l}\text { Rasio Lancar } \\
\text { (dalam bentuk persen) }\end{array}$ & $95,2 \%$ & $99,7 \%$ & $114,2 \%$ & $148,4 \%$ \\
\hline Rata-rata & \multicolumn{4}{|c|}{$114,375 \%$} \\
\hline
\end{tabular}

Sumber: data diolah, 2017.

Pada perhitungan di atas bisa dilihat bahwa rasio lancar di PT. Siantar Top Tbk fluktuatif tidak tentu kenaikan dan penurunan setiap tahunnya. Diketahui rasio lancar pada tahun 2011 adalah 95,2\% sehingga setiap Rp. 1 hutang lancar dijamin pengembaliannya oleh aktiva lancar sebesar Rp. 0,952 dan untuk rasio lancar dalam jumlah seperti ini termasuk kategori tidak baik. Rasio Lancar pada tahun 2012 adalah 99,7\% sehingga setiap Rp. 1 hutang lancar dijamin pengembaliannya oleh aktiva lancar sebesar Rp. 0,997 dan untuk Rasio Lancar tahun 2012 dalam jumlah seperti ini termasuk dalam kriteria tidak baik, tetapi terdapat kenaikan rasio lancar dari tahun 2011-2012 sebesar 4,5\% hal ini disebabkan bertambahnya aktiva lancar dan hutang lancar.

Rasio Lancar pada tahun 2013 sebesar 114,2\% sehingga setiap Rp. 1 hutang lancar dijamin pengembaliannya oleh aktiva lancar sebesar Rp. 1,142 dan untuk rasio lancar pada tahun 2013 termasuk kedalam kriteria tidak baik karena menurut Peraturan Menteri Negara Koperasi dan Usaha Kecil dan Menengah Republik Indonesia, Nomor 06/Per/M.KUKM/V/2006 tanggal 1 Mei 2006 tentang Pedoman Penilaian Koperasi Berprestasi/koperasi award dalam Pratama (2016: 40) bahwa $(<125 \%$ atau $>325 \%=$ Tidak baik). Perbandingan antara tahun 2012 dengan tahun 2013 adalah terjadinya kenaikan rasio lancar karena kewajiban lancar atau Utang naik.

Pada rasio lancar tahun 2014 sebesar 148,4\% jadi setiap Rp. 1 hutang lancar dijamin pengembaliannya sebesar Rp. 1.484 oleh aktiva lancar, rasio lancar pada 
tahun ini dikategorikan kurang baik, tetapi terlihat dari table di atas terjadi peningkatan yang signifikan dari tahun 2011 sampai dengan 2014.

\section{Rasio Profitabilitas \\ Profit Margin}

Tabel 3

Hasil Perhitungan Profit Margin Periode 2011 - 2014

(dalam mliyar rupiah)

\begin{tabular}{|c|c|c|c|c|}
\hline Keterangan & 2011 & 2012 & 2013 & 2014 \\
\hline $\begin{array}{c}\text { Profit Margin } \\
\text { (dalam bentuk decimal) }\end{array}$ & 0,041 & 0,058 & 0,067 & 0,056 \\
\hline $\begin{array}{c}\text { Profit Margin } \\
\text { (dalam bentuk persen) }\end{array}$ & $4,1 \%$ & $5,8 \%$ & $6,7 \%$ & $5,6 \%$ \\
\hline Rata-rata & \multicolumn{3}{|c|}{$5,55 \%$} \\
\hline
\end{tabular}

Sumber: data diolah, 2017.

Dari tabel di atas dapat disimpulkan bahwa kinerja keuangan perusahaan pada tahun 2011 tidak sehat $(1 \%$ s/d < 5\%) karena perusahaan melakukan penjualan yang banyak tetapi mendapatkan laba yang sedikit. Hal ini disebabkan karena ketidak efisienan manajemen sehingga tidak bisa menekan biaya-biaya di perusahaan secara efisien. Pada tahun 2012 dan 2013, perusahaan mengalami peningkatan yaitu 5,8\% dan 6,7\% walaupun dalam angka ini perusahaan masih dalam kondisi kurang baik, dan pada tahun 2014 perusahaan mengalami penurunan lagi.

Profit Margin merupakan kemampuan perusahaan menghitung sejauh mana kemampuan perusahaan menghasilkan laba bersih pada tingkat penjualan tertentu. Profit margin PT. Siantar Top Tbk pada tahun 2011 tidak sehat (1\% s/d $<5 \%$ ) karena perusahaan melakukan penjualan yang banyak tetapi mendapatkan laba yang sedikit. Pada tahun 2012 dan 2013, perusahaan mengalami peningkatan yaitu $5,8 \%$ dan $6,7 \%$ walaupun dalam angka ini perusahaan masih dalam kondisi kurang baik, dan pada tahun 2014 perusahaan mengalami penurunan lagi sebesar 5,6\%. Penelitian ini sejalan dengan hasil penelitian Manik (2016) yang menyatakan bahwa rasio profitabilitas menggunakan profit margin tidak baik pada perusahaan.

EVA

Tabel 4

Perhitungan Economic Value Added (EVA) Periode 2011-2014 (dalam bentuk milyar)

\begin{tabular}{|c|c|c|c|c|}
\hline Keterangan & 2011 & 2012 & 2013 & 2014 \\
\hline $\begin{array}{c}\text { EVA } \\
\text { (dalam bentuk decimal) }\end{array}$ & $-6379133,756$ & 4648549,582 & 1137550,607 & $-31045406,79$ \\
\hline $\begin{array}{c}\text { EVA } \\
\text { (dalam bentuk persen) }\end{array}$ & $-637913375.6 \%$ & $464854958.2 \%$ & $113755060.7 \%$ & $-3104540679 \%$ \\
\hline Rata-rata & \multicolumn{3}{|c|}{$-790958509 \%$} \\
\hline
\end{tabular}

Sumber: data diolah, 2017. 
Berdasarkan tabel 4 pada tahun 2011 dapat dilihat bahwa kinerja keuangan PT. Siantar Top Tbk berdasarkan EVA memiliki nilai negatif (EVA < 0). EVA pada tahun 2011 yaitu RP - 6379133,756, kondisi EVA tersebut merupakan perolehan terkecil dibandingkan dengan tahun-tahun lainnya. Menurut Sawir dalam Wardani (2014:31), EVA bernilai negatif karena perusahaan tidak mampu mencukupi kebutuhan dalam memenuhi kewajiban sehingga perusahaan tidak mampu menciptakan nilai karena laba yang dihasilkan tidak mencukupi untuk menyandang dana terutama pemegang saham.

Pada tahun 2012, kinerja keuangan PT. Siantar Top Tbk berdasarkan EVA mengalami kenaikan dari tahun sebelumnya, yaitu Rp 4648549,582. Kenaikan EVA tersebut dipengaruhi laba operasi perusahaan yang mengalami peningkatan. Menurut Sawir dalam Wardani (2014:31) EVA positif menunjukkan bahwa perusahaan mampu menciptakan nilai melalui kegiatan operasional sehingga perusahaan tidak hanya mampu membayar seluruh kewajibannya, namun juga mampu menghasilkan laba yang lebih bagi perusahaan.

Pada tahun 2013, kinerja keuangan perolehan EVA mengalami penurunan namun masih mampu mempertahankan nilai positif sebesar Rp 1137550,607. Pada Tahun 2014, kinerja keuangan PT. Siantar Top Tbk mengalami penurunan derastis yaitu Rp - 31045406,79. Hal ini disebabkan karena perusahaan tidak mampu menciptakan nilai karena laba yang dihasilkan tidak mencukupi untuk penyandang dana terutama pemegang saham.

\section{KESIMPULAN}

1. Hasil rasio likuiditas PT. Siantar Top Tbk periode 2011 - 2014 menunjukkan bahwa rasio lancar masih belum memenuhi standar industri yang telah ditetapkan karena nilai rasio masih di bawah standar industri. Hal ini dikarenakan kemampuan perusahaan dalam menutupi hutang lancar dengan aktiva lancarnya sangat rendah.

2. Hasil rasio keuangan profitabilitas PT. Siantar Top Tbk periode $2011-2014$ menunjukkan bahwa profit margin dalam keadaan kurang baik dikarenakan antara laba bersih dan modal saham tidak simbang atau lebih banyak modal sahamnya sehingga perusahaan tidak dapat menciptakan laba yang lebih besar dibandingkan dengan modal saham.

3. Hasil EVA PT. Siantar Top Tbk periode 2011 - 2014 menunjukkan bahwa pada tahun 2011 memiliki nilai negatif karena perusahaan tidak mampu mencukupi kebutuhan dalam memenuhi kewajiban, pada tahun 2012 EVA mengalami kenaikan karena dipengaruhi laba operasi perusahaan yang mengalami peningkatan, pada tahun 2013 - 2014 EVA mengalami penurunan.

\section{SARAN}

Bagi Perusahaan:

1. PT. Siantar Top Tbk harus lebih memperhatikan penggunaan dan pengelolaan aktiva dan modal penggunakan yang diperoleh karena itu akan berdampak pada tingkat rasio-rasio perusahaan. 
2. Pengelolaan aktiva dan modal harus ditingkatkan agar menghasilkan laba dan penjualan yang seimbang dan meningkat.

3. PT. Siantar Top Tbk harus berorientasi pada penciptaan nilai tambah dalam kegiatan operasionalnya agar dapat mempertahankan nilai EVA yang positif.

4. Perusahaan juga harus mampu meningkatkan NOPAT dan menurunkan biaya modal agar nilai EVA positif setiap tahunnya.

Bagi Penelitian Selanjutnya:

1. Sebaiknya perusahaan menggunakan rasio profitabilitas lain seperti ROA dan ROE karena PT. Siantar Top Tbk jika dihitung dengan rasio profitabilitas dengan ROA dan ROE kemungkinan akan menghasilkan laba yang lebih banyak dari pada modal saham.

2. Harap memperhatikan sektor industri yang akan diteliti, apakah industri tersebut cocok atau tidak dengan rasio yang akan digunakan untuk penelitian selanjutnya.

\section{DAFTAR PUSTAKA}

Rahardjo, Budi. 2007. Keuangan \& Akuntansi untuk Manajer Non Keuangan. Yogyakarta: Graha Ilmu

Hanafi, Mamduh M. 2015. Manajemen Keuangan. Yogyakarta: BPFE-Anggota IKAPI.

Harnanto. 1991. Analisis Laporan Keuangan. Yogyakarta: Unit Penerbit dan Percetakan AMP YKPN

Pratama, Heru Andika Hilarius. 2016. Analisis Kinerja Keuangan Berdasarkan Rasio Likuiditas, Solvabilitas, dan Rentabilitas pada Koperasi CU Dharma Hstiku. Yogyakarta: Universitas Sanata Dharma

Rudianto. 2012. Pengantar Akuntansi Konsep \& Teknik Penyusunan Laporan Keuangan. Jakarta: Erlangga

Sugiono. 2002. Metode Kuantitatif, Kualitatif, dan $R \&$ D. Bandung: Alfaberta

Laporan keuangan PT. Siantar Top Tbk tahun 2011

Laporan keuangan PT. Siantar Top Tbk tahun 2012

Laporan keuangan PT. Siantar Top Tbk tahun 2013

Laporan keuangan PT. Siantar Top Tbk tahun 2014 